\title{
Liberal outcomes through undemocratic means: the reform of the Code de statut personnel in Morocco*
}

\author{
Francesco Cavatorta
}

School of Law and Government, Dublin City University, Glasnevin, Dublin 9, Ireland

Email: Francesco.cavatorta@dcu.ie

and

\author{
Emanuela Dalmasso
}

Department of Political Science, University of Turin, IOI24 Turin, Italy

Email: emanuela.dalmasso@gmail.com

\section{A B S T R A C T}

The 2004 reform of the family code in Morocco has been held as one of the most significant liberal reforms undertaken in the country, and has led scholars and policy makers to argue that this demonstrates the democratic progress Morocco and the King are making. At the same time, the role of the women's movement in getting the reform approved has seemingly confirmed that associational life is crucial in promoting democratisation. This paper, building on theoretical work questioning the linkage between a strong civil society and democratic outcomes, argues that civil society activism does not necessarily lead to democratisation, and may reinforce authoritarian practices. Far from demonstrating the centrality of civil society, the process through which the new family code was passed highlights the crucial institutional role of the monarch, whose individual decision-making power has driven the whole process. Authoritarianism finds

* The authors are very grateful to the anonymous referees for their very helpful comments. We also wish to acknowledge the DCU Career Start Programme for the financial aid provided to carry out the field work for this article. Finally, both authors wish to thank the Centre for Contemporary Middle East Studies, University of Southern Denmark, for the support received during Francesco Cavatorta's sabbatical there in 2008/9. 
itself strengthened in Morocco despite the liberal nature and outcome of the reform.

\section{N T R O D U G T I O N}

When in October 2003 King Mohammed VI presented for approval to the Moroccan parliament his project of substantial reform of the Code de statut personnel or Moudawana, with the aim of introducing a much higher degree of legal equality between men and women, this was heralded as one of the most fundamental victories for the modernising and liberal forces in the country. Women's rights associations in particular celebrated the introduction of the new legislation for which they had struggled for over two decades. Suddenly, years of petitioning, marching, organising and confronting the more conservative elements of society, including vast sectors of political Islam, paid off, and the king delivered what the women's movement had asked him after the failure of the government to adopt an earlier plan, the Plan d'Action National pour l'Intégration de la Femme au Development (PANIFD), which was less ambitious in terms of the scope of the reform (Jbabdi 2009 int.).

The enthusiasm with which this watershed reform was received in liberal circles both inside and outside Morocco led scholars and activists to argue that the reform of the Moudawana 'was a prelude to the democratisation of the country' (Benradi et al. 2007). The reform was examined in the context of other important symbolic gestures that King Mohammed VI made in the early days of his reign after succeeding his father in I999, such as the dismissal of the very powerful and deeply unpopular Minister of Interior Driss Basri, and the public appearances of Royal Princess Lalla Salma. Thus, the radical reform of the Code that the king personally pushed through was interpreted simply as another move towards the democratisation of the country. One of the main lessons learned during this time was that the victory of the women's rights movement seemed to demonstrate the validity of the assumption that democratisation could be achieved through civil society activism, as it had struggled for decades to achieve a comprehensive reform of the family code. This is in line with the dominant thinking about the relationship between democratisation and civil society activism, particularly within the international donor community.

This paper, while not underestimating the impact of the reform of the Moudawana in establishing a considerable degree of equality between the sexes, and placing liberal rights at the centre of social relations, argues that such a liberal outcome has been obtained through undemocratic mechanisms and processes and that, far from constituting a prelude to 
democratisation, the reform is a testament to the arbitrary nature of political authority in Morocco. This has significant implications not only for the concrete implementation of the new Code, but for our understanding of the relationship between civic activism and democratisation. This does not mean that civil society activism does not influence political change, but simply implies that the nature of such change may not necessarily lead to democracy understood as genuine political pluralism with elected and accountable decision-makers (Sater 2007). The contention here is that the reform of the Code represents indeed a fundamental transformation in Moroccan society with the recognition in particular that social modernisation requires a rebalancing of rights in favour of the individual over the collective, but that these changes do not alter the distribution of political power in favour of effective pluralism. On the contrary, as demonstrated by Jamal (2007), it can be argued that the ways in which civil society operates strengthens the authoritarian nature of the political system and that, in Morocco, the king managed to reassert his grip on power by presenting himself as the defender of women's rights: le Roi des femmes.

Kubba (2000) argued that 'the awakening of civil society' in the Arab world would lead to democracy. Due to the weakness of established political parties and their inability to produce political and institutional change (Willis 2002), the task of transforming society and leading it out of political authoritarianism would fall to civil society activists. Kubba's optimistic view of the role of civil society, understood as 'the realm of organised social life that is voluntary, self-generating, (largely) self-supporting, autonomous from the state and bound by a legal order or set of shared rules' (Diamond I994: 5), was due to three factors. First, there is the theoretical assumption, dominant within democratic theory (Gellner I994; Putnam 2000), that there is a strong link between civil society and democracy. In this context, civil society activism is an inherently positive phenomenon and directly contributes to the sustenance of democracy where it exists, and to the weakening of authoritarianism where democracy is not yet in place. In democratic theory, the concept of civil society is synonymous with liberal and democratic values, as civic engagement is the manifestation of the autonomy of the individual and the organisations that she or he decides to belong to. The second factor is the democratising experience of countries in Eastern Europe and Latin America, where transitions to democracy were partly explained through the crucial role of civic activism in subverting authoritarian rule (Rau I99I). Finally, there is no doubt that the 
Arab world, with some exceptions, is indeed witnessing an 'explosion' (Howe 2005) of a plethora of civil society organisations which seems to indicate that genuine pluralism is becoming a reality.

Such an optimistic reading of the link between civil society and democratisation, and therefore of the social and political reality of the Arab world, is however strongly criticised in some quarters. From a theoretical point of view, the very definition of civil society and its normative connotation are controversial, as they do not provide much analytical value (Berman 2003; Carothers I999; Encarnacion 2006). Diamond's definition for instance does not tell us very much about the pro-democratic direction of the growth of associational life. Diamond's argument implies that the growth of activism is linked to increasing demands for political pluralism and participation. This 'implication' is however problematic. It seems theoretically unsound to argue that there is an inevitable link between activism and democracy, if the very concept of civil society is shed of its normativity and simply becomes a neutral analytical tool. As far as the empirical evidence from the cases of Latin America and Eastern Europe is concerned, it emerges that the early studies accounting for democratisation in terms of the presence of a strong civil society overemphasised its role (Tempest 1997). Finally, the explosion of civil society in the Arab world, while corresponding to the truth in sheer numerical terms, should be examined with a degree of scepticism given the close proximity of many organisations to the ruling elites, and the role of social control that they perform on behalf of authoritarian regimes (Wiktorowicz 2000).

Despite the existence of such a critical take on the real influence of civil society in the Arab world, the reform of Moudawana in Morocco has mostly been interpreted as a stunning victory for civil society in the name of democracy and human rights (El-Ghissassi 2006). This has led both scholars and policy makers to praise the democratising efforts of the country, and Morocco's international reputation improved quite dramatically after the promulgation of the new Code, with the international community giving the country a 'good democrat certificate'. This allows the regime to enjoy significant economic benefits and political legitimacy. For instance, in $200 \mathrm{I}$ the EU's judgement on Morocco's political liberalisation was positive but not enthusiastic, as the EU considered that in Morocco 'significant progress in terms of individual freedoms and fundamental rights ${ }^{1}$ had been made. However, in the Country Strategy Paper EU-Morocco 2007-2013, Morocco is described as the most advanced country on the southern shore of the Mediterranean regarding the democratisation process and the construction of a system governed by the rule of law. ${ }^{2}$ This very positive judgement is largely due to the promulgation of the new Moudawana, and 
allows the regime to point to the expanding associational life of the country as evidence of democratic progress. More importantly, the reform seemed to confirm the central role of civil society activism in leading to institutional and legal democratisation. Christiansen (2004) argues that 'aside from the new family law, there has only been limited progress towards democracy', indicating a degree of scepticism about the pace of reforms, but implicitly equating the reform of the code with democratic progress. It is believed that the activism of women's rights organisations not only contributed to an increase in social capital (Sadiqi 2008), but had a significant impact on the perceived democratisation of the polity because of the degree of pluralism expressed in the public sphere during the debate about the reform, and because of the individualisation of rights that the new code subscribed to, thereby meeting the requirements of liberal legislation underpinning a new political order.

In her study of the relationship between social and legal changes, Wuerth (2005) specifically analyses the role for women's organisations in Morocco and their efforts to have the new legislation approved. She argues convincingly that the new law reflects deep social changes and that it will in turn further modify social behaviour. It therefore emerges that a seemingly democratising trend has been generated. In this context, it is worth remembering that the old family code had been used by the monarchy immediately after independence to cement its alliance with the tribes in the rural areas. In exchange for political support against the nationalist party, the king guaranteed the primacy of collective rights over individual ones when it came to family law (Charrad 200I). The 2004 Moudawana fundamentally undermined the primacy of collective rights, and therefore weakened traditional social cohesion when it came to the creation of marriage ties, by introducing more liberal and individualistic provisions regulating such matters. The changes reflected the most important concerns of the liberal sectors of society, and the reform itself, from a liberal-democratic perspective, is a significant improvement on the past and a 'good' reform. A number of crucial provisions have been introduced, such as removing guardianship for a woman in order to get married once she has come of age; moving the minimum age at which women can marry from fifteen to eighteen; severely restricting polygamy; significantly expanding the possibility for women to initiate divorce procedures; and mandating that repudiation be a matter of judicial supervision. ${ }^{3}$ Thus, the conventional wisdom is that the new family code was approved through a combination of effective advocacy and lobbying on the part of women's associations at both the national and international level. Both Saida Drissi (2008 int.) of the Association Démocratique des Femmes 
$d u$ Maroc (ADFM) and Bouchra Abdou (2008 int.), member of the Bureau National of the Ligue Démocratique pour les Droits des Femmes (LDDF), confirmed that the work of their associations largely consists in relentlessly lobbying the government to expand and protect women's rights. In turn, the approval of the new legislation was read as a significant step towards the establishment of genuine democratic changes and rule of law. Maghraoui (2008: 194), despite his sceptic take on overall progress towards democracy in the country, argues that 'the participation of civil society in royal committees has been relatively effective in giving them more legitimacy'.

This reading and the widespread acceptance of the positive 'Moudawana effect' on democratisation in Morocco is however problematic when one closely examines the role of civil society under authoritarian constraints, and the way in which the process of promulgation of the reform itself took place. There is today a significant amount of theoretical work claiming that civil society dynamics under authoritarian rule are very different from those in established democracies (Clark 2004; Jamal 2007; Liverani 2008). The argument is that the authoritarian constraints put in place by the regime make it necessary for civil society associations to decide how best to operate to fulfil their organisational mandate and achieve their objectives within the given constraints. This leads the vast majority of them not to challenge authoritarian practices openly, but to work through them. If an association wants to achieve some of its objectives, and therefore see its preferred policy implemented, it has to play by the rules of the authoritarian regime. Thus, for example, it is only through networks of patronage and privileged links with the real wielders of power that the association will be able to satisfy the basic needs of its members and achieve its goals, because only the regime and its representatives can ultimately deliver the 'goods'. All this inevitably strengthens authoritarian practices. This does not mean that there are no civil society movements that refrain from using such privileged networks and prefer to have no relations with the ruling authorities, but the scope and the degree of success they can achieve is limited.

Organisations that refuse to play within the given constraints, or that cannot do so because of their own structural weaknesses or because they are too controversial politically, have a much harder task to obtain the objectives they have set, face harassment from the authorities, and are ignored and/or deprived of funds. For example, according to the Moroccan legislation, associations need to have a licence from the state authorities if they want to operate legally. Obtaining the licence from the relevant ministry is however not straightforward, and largely depends on how 'political' the association is. Thus, the association Ennasir, which defends 
the prisoners of the Islamist al-Salafyia al-fihadia and does charitable work for the families of the prisoners, operates without a licence and is subject to all sorts of harassment by the authorities such as the break-up of sit-ins or press conferences. This occurs because without the licence the association is not a recognised legal entity and has no recourse to the justice system. A further problem is funding, because without the licence it is very difficult to raise funds and this is even more difficult when funds come from abroad. In order to circumvent these problems, many groups rely on friends or relatives within the administration to speed up the bureaucracy. If however, as in the case of Ennasir, the work of the groups is highly controversial, no amount of wasta (connections) can help.

Given the central role of the monarchy in Morocco and its significant executive powers, the country cannot be considered a democratic regime, but is at best a 'liberalised autocracy' (Brumberg 2002). The constitution assigns extensive powers to the monarch, who appoints the prime minister, chairs cabinet meetings, and has exclusive appointment powers over crucial ministries such as Interior and Foreign Affairs. In addition he is in charge of setting national priorities with the support of his close, and unelected, advisers. Finally, the king appoints regional governors. If this were not sufficient to make the monarch the real decision-maker, it should be highlighted that he enjoys enormous religious legitimacy as Commander of the Faithful and is, in theory, the sole interpreter of Islam in the country. These powers inevitably marginalise the elected Parliament and the political parties. Thus, in analysing Moroccan civil society, one must take into account that there are authoritarian constraints in place which all movements have to contend with, because elected officials are not necessarily crucial interlocutors. Sater (2007: 164-5) for instance argues that 'apart from a few exceptions [civil society groups] are by no means in opposition to the state. In fact ... most of them ... display self-limiting features.' This indicates that associations are aware that they cannot consistently antagonise the authorities if they wish to continue to operate. Obviously, there are also groups in Morocco that refuse to play within the given constraints, but these know they have to pay a price in terms of harassment or refusal of permits and funds. Some Moroccan activists confirm that this is the case in practice. Khalil Jemmah (2008 int.), vice-president of the Association of Friends and Families of the Victims of Illegal Immigration (AFVIC), claims that 'one of the rules of psychological torture for the Makhzen' is to ignore the existence of associations that are active and independent'.

For example, within the context of the National Initiative for Human Development (INHD), launched by the king in 2005 in order to favour the development of the most disenfranchised sectors of the population, it is 
claimed that the management of the initiative by the Ministry of Interior through the local administrations has led to what activists label the 'domestication of associational life' (Jemmah 2008 int.; Akesbi 2008 int.). This simply means that the distribution of grants to different groups for carrying out social and economic programmes occurs not on the basis of merit, but on the basis of what can be termed political quietism. For associations that the authorities perceive as bothersome, the stick of harassment and denial of money is employed, while for the ones aligned to the regime, the so called associations oui-oui, there is the carrot of grants for their projects. Still referring to the INDH, Said Tbel (2008 int.) of Espace Associatif claims that all 'those who have very little to do with development, but might simply have electoral or personal interests, create associations just to get money from the INDH', indicating that associational life within the realm of development has become an instrument for the regime to distribute money through which it can then directly and indirectly control associations and stifle criticism and genuine opposition. Referring to the general problems of Moroccan associational life, Azzedine Akesbi (2008 int.) expressed the same idea, claiming for instance that genuine opposition associations are not granted the license of utilité publique, which is necessary to enjoy non-profit legal status. This status allows the organisation a degree of financial autonomy, for instance by being able to receive tax deductible private donations, which have a positive effect on the political independence of the association itself.

The radical reform of the Moudawana cannot be fully understood if one does not take into account the environment described above within which associations have to operate. Far from questioning the legitimate claims of the women's rights movements, the degree of their genuine engagement and the positive liberal nature of the new legislation, the argument here is that this does not reflect an intrinsic democratisation of the Moroccan polity, and the reform is not a step towards genuine political change. To the contrary: when one looks at the historical process and manner in which the new family code was brought into existence, it can be claimed that it simply reinforces the central role of the monarchy as the ultimate, and unelected, arbiter of major policy decisions concerning the country. This means bypassing the supposedly democratic institutions such as the Parliament and the government that have been central to the democratic self-image of Morocco at home and abroad. As Khalil Jemmah (2008 int.) points out, 'government is perceived as a group of employees ... who execute policies ... which have been decided elsewhere'. Tuquoi (2006: 205) adds that 'the government ... is nothing but a rubber-stamp institution and a transmission belt between the throne and public administration'. 
This is true for the policy process that led to the promulgation of the new Moudawana. Thus, while the procedural dimension of democracy formally exists, the substantive aspect is entirely neglected in favour of decisionmaking within the royal court. This leads to the depoliticisation (Maghraoui 2002) of the population vis-à-vis the supposedly democratic institutions and procedures, as the extremely low turnout at the 2007 legislative elections demonstrates (Storm 2008). It follows that political change becomes dependent on the coincidence of interests between the king and the concerned social group, whereby the most important condition is the unquestioned power of the king to shape the policy environment. This does not mean that the king can do whatever he pleases at all times, but it does mean that his role in shaping policy making is crucial.

THE ROLE OF THE MONARGHY IN THE REFORM OF THE $M O U D A W A \mathcal{N} A$

The opposition between tradition and modernity in Morocco has been used to create a fictitious watershed between the reign of Hassan II and that of his son Mohammed VI. Development, democratisation, respect for human rights and implementation of the rule of law have become the creed of the Makhzen under Mohammed VI, as if an entirely new era started with the new modern king. Inevitably the reform of the family code has been an integral part and a powerful symbol of this new era of supposedly radical change for Morocco. On a closer analysis, however, it emerges that the process of democratisation in Morocco is much more complex than the linear development that one traditionally expects, and that the reform of the family code, like many of the other reforms implemented over the last decade, is part of a redefinition of the authoritarian system and its transformation into 'pluralist authoritarianism' (Leca in Liverani 2008: xiii). First of all, it is important to highlight that liberalising reforms had started already under Hassan II, and that the economic liberalisation of the early I99os went along with cautious political openings (Willis I999). By the end of the Cold War, the strong authoritarianism of the system had become gradually more 'expensive', especially in the international democratisation market where traditional allies such as France and the USA were hardening their positions towards authoritarian rulers and pressing for some change (Cavatorta 2005). The limited political openings were soon exploited by the women's movement. The UAF (Union de l'Action Féminine), in defiance of the king's expectation that the beginning of liberalisation would be met with social peace to allow him to work on constitutional changes, launched the 'one million signatures campaign' with the aim of pressurising the Parliament to tackle the issue of the reform of the 
Moudawana. The UAF asked for a thorough revision of the family code, including the end of polygamy, the end of tutelage, a minimum age for marriage and judicial divorce (Sadiqi 2002: 28). More generally, it sought legal equality between men and women.

With this spectacular move the women's movement found itself at the forefront of the struggle for democratisation. As other social and political actors waited for Hassan to deliver the changes he had promised, women activists mobilised vast sectors of the population in support of their demands. The most interesting aspect of this campaign was that the UAF addressed its demands for reform not directly to the king, but to the Parliament and the prime minister. This was a testament to its democratic attitudes and was intended to link its particularistic interests to a much wider agenda for change. Addressing elected officials rather than the monarch indicated that the reform should be the outcome of a democratic parliamentary debate. The demands for reform aroused the opposition of the most conservative sectors of society, including official ulemas, and this obviously presented a problem for the women's organisations, as traditionalists had considerable power both within the ruling elites and in society. However, according to Jbabdi (2009 int.), the political parties that were taking part in the on-going process of controlled political liberalisation also accused the women's movement of creating unwelcome difficulties to the wider process of political opening. It is at this stage that the king intervened to confiscate the debate. Hassan II wanted to avoid a political confrontation at a time when he required social peace to implement some liberal reforms. Being the Commander of the Faithful, he claimed that the issue of Personal Status Law was his prerogative and so Moroccan women had to address their complaints to him, and not mix them up with political issues. In an official speech of August 1992 Hassan II stated: 'Be advised my dear Daughter, Moroccan Woman, that the Moudawana is above all a matter of my remit. ${ }^{5}$

Royal intervention ensured that the issue remained outside institutional politics and, at the same time, marginalised the women's movement emanating from civil society. The king in fact, after initially holding a meeting with the promoters of the campaign, chose different interlocutors and finally met officially with women from the political parties who had done very little in terms of promoting change in the family code. As Amar (2009: 80) highlights, Hassan II 'hosted in September I992 a delegation of women at the royal palace ... but was very careful in not inviting the promoters of the one million signatures campaign'. Conscious of the opposition of the ulemas to radical changes, and undermined by the more militant sector of the women's movement, the king introduced a minor 
reform in 1993. While it is true that the monarch intervened and monopolised the debate about the reform, the changes introduced in i993 reflected the pressure that the public could exercise, to a certain degree, on the main decision-maker. Having made the family code a political issue in the context of democratisation did not lead to a radical change of the legislation, but forced Hassan II to consider how his liberalising moves were influencing the perceptions and strategies of the other players in the system. Furthermore, many activists within the women's movement were very much against the idea of appealing to the monarch, precisely because it was perceived to be a step that would reinforce authoritarianism. This means that within the women's movement there was an awareness of the precarious balance between the desire for a reform and the means through which it could be obtained. There is therefore very little doubt that 'the relatively limited reform of Moudawana in I993 was closely linked to the beginnings of a process of cautious democratisation' (Buskens 2003: 7I). This is an important point to make because the manner in which the reform of 2004 was obtained was superficially similar, but substantively different.

The opportunity for the women's movement to put the reform of the family code on the table once again came in the late I99os, when Hassan II decided that parties from the longstanding opposition such as the Socialist Party (UFSP) should be integrated into the political system and afforded a chance to govern. An agreement was struck between the king and the opposition parties, whereby the former retained a number of significant executive prerogatives, but the latter would be allowed access to some executive power. The government of alternance was established in I998, and the left-wing liberal forces within the cabinet allowed for the opening up of the debate about further reform (Buskens 2003). Minister Said Saadi, a member of the left-wing Parti du Progrés et du Socialisme (PPS), which in turn is linked to the Association Marocaine pour les Droits des Femmes (ADFM), set up a working group that included members of the women's movement to examine the issue of the reform of the family code, following the outcome of a series of international conferences on the role of women in development. The working group, after wide consultation with ministries, trade unions and civil society organisations, wrote the PANIFD, which became the document for the reform that the government was meant to adopt.

The World Bank financed the plan and three leading Moroccan women's associations, the ADFM, the UAF and the AMDF, wrote it, finding in the process a new forum to discuss women's rights (Roussillon \& Zryouil 2006), although Jbabdi (2009 int.) argues that in the end the ADFM 
monopolised the writing of the Plan. By this time Hassan II had passed away and Mohammed VI was in power. The issue of development had become the chimera to pursue in the Moroccan political arena, and this coincided with economic liberalisation, which required legislation that would privilege individual rather than collective rights. In this respect, the role that international financial institutions had designed for women as protagonists of economic development meant that Morocco had to incorporate this philosophy into legislation (Ennaji 2008). The question of a thorough reform of the family code in a much more liberal direction was therefore high on the agenda. Prime Minister Youssufi had accepted the validity of the demands of the women's movement by stating that he wanted to 'harmonise domestic legislation in line with the international engagements Morocco undertook on matters related to the promotion of women's fundamental rights' ${ }^{6}$

Thus, in addition to the ideological proximity between some ministers in the USFP-led cabinet and the women's movement, the link with the international dimension had a crucial importance for re-introducing the issue of the reform of the Code in the political arena. First of all it allowed the women's movement to gain the ear of powerful figures in government because it was linked to the developmental discourse, which, being a priority for the monarchy, made government officials well predisposed towards them. Secondly and more significantly, having learned from the I993 experience, the women's movement involved King Mohammed VI, who had declared the promotion of women's rights a priority. The linkage with the issue of development was particularly suited to have the king on board. However, strong opposition to demands for reform of the family code came from the Islamists and other traditionalists, including the powerful minister for religious affairs M'Daghri Alaoui. The reform project included in the PANIFD got 'stuck' within the democratic process, as the cabinet was suddenly divided over it and the government withdrew support for the Plan.

The conflict over the reform was then played out in the streets. The 'battle of the marches' of I2 March 2000 saw the Islamists emerge as clear winners, as they were able to organise a huge demonstration against the reform, with considerably more participants than the march in its favour organised by the women's movement on the same day. This show of strength by the Islamists and other traditionalists had not occurred in I993, when the women's rights movement faced an Islamist opposition with little formal organisational capacity, and under the control of Hassan II. During the I990s, however, Islamism had grown considerably in strength, and it was now a formidable opponent for both the secular sectors of society and 
the monarchy (Zeghal 2005). Mohammed VI had to tread carefully in this polarised debate, conscious that in the 'new' Morocco he wished to represent he could not simply close down the debate as soon as strong social conflicts emerged, as his father had previously done.

It is at this juncture that the women's movement, fearful that the reform would not be introduced, addressed the king directly, bypassing the obstacle of the elected institutions. Thus, while in I993 the petition was sent to the Prime Minister and the Parliament, in March 200 I the network of feminist associations Spring for Equality sent the king a memorandum on its aspirations concerning the reform. The king received the promoters, made a brief speech and then set up a Royal Commission to discuss the potential reform of the family code. As Zvan (2007: 86) points out, 'the commission consisted of three women and thirteen men, representing both traditionalist elements as well as liberal ones. Driss Dahak, first president of the Supreme Court as well as the president of the official body for human rights, was appointed chair of the Commission.'

The Commission at first sent quite negative signals to the women's movement about the extent of the changes, and so the movement had no alternative but to involve the king even more directly. Mohammed VI did indeed twice intervene directly in the Commission's work (Zvan 2007), replacing Dahak because he was not happy with the progress that the Commission was making (Amar 2009). The choice of reliance on the king was not an easy one for the women's movement. It was obvious that this reliance would strengthen the monarchy and undermine the progress towards democratisation, because Mohammed VI would be greatly empowered and, unlike in I993, the women's movement had gone directly to the king. The desire to see the reform introduced nonetheless prevailed, even if this meant that the king appropriated the issue of women's rights for himself, relegating civil society to the margins (Amar 2009: 85). In conclusion, the show of force of the Islamists and traditionalists in March 2000 convinced the leading associations within the women's movement that to obtain the reform, they had to bypass the democratically elected institutions and address the king directly, as the only person able to deliver it.

During this time, it became clear that two opposing trends within civil society were solidifying. One was the women's movement of leftist and liberal orientation, pushing very strongly for a thorough reform that would meet international criteria on individual rights and equality. The other was traditional and conservative elements within Moroccan society, including vast sectors of Islam, who either desired no change to the family code in the name of the defence of collective rights over individual ones, or 
else favoured modifications to the law only if steeped into Islamic references and not as the product of what they perceived to be Western cultural imperialism. As one of the leaders of the Justice and Charity Group, Nadia Yassine (2008 int.), argued, the women's movement realised that most Moroccans and, more importantly, the political parties, which are accountable to voters, would be opposed to a change in the family code, and it could therefore no longer link its demands to wider demands for democratisation as it had done in 1993 .

The Royal Commission worked on the reform for two years, but the monarch was not yet ready to come down decisively in favour of the women's movements because of the continuous rise of radical Islam, which was also fuelled by international events (Beau \& Graciet 2006). As Clark and Young (2008) correctly point out, however, the opportune moment to fully utilise his religious authority and executive powers on the issue of the Moudawana came after the Casablanca bombings of 2003, which were carried out by a violent Islamist group, al-Salafyia al-fihadia. At this time, the whole vast field of political Islam was silenced in what the king termed the 'end of the era of leniency', and he saw the opportunity to force the new legislation through Parliament and to satisfy the demands of the women's rights movement. Indeed, a columnist for the Oumma website wrote that the project of the reform 'arrived in Parliament as if it were a divine decree'. ${ }^{7}$ The same point is made by Amar (2009), who argues that the decree was imposed on reluctant political parties, strengthening the role of the monarch as ultimate decision-maker. The women's movement obviously celebrated its victory; and the Islamists, with different degrees of reluctance, came around and supported the reform because the legislative text did indeed contain references to specific Islamic values and traditions, while the PANIFD did not. In fact, the PANIFD largely failed because it contained no reference to religion, which was in line with the strict secular ethos of many within the women's movement.

What emerges quite clearly is that the manner in which the reform was passed therefore reinforced the central role of supreme arbiter that the monarchy enjoys. The king and his entourage needed a showcase reform for international purposes, and to justify the domestic discourse of development which was fully linked with the neo-liberal economic project. Thus, at the opportune moment and conscious of the domestic balance of forces between modernists and traditionalists (Zvan 2007), the king utilised his roles both as Commander of the Faithful and as leading executive power in the country to force through a reform that bypassed the political parties, civil society organisations and elected institutions. This does not mean that there was no public debate; quite the contrary is true. However, 
there is no doubt that such debate did not matter much in the end because the king made a decision and overruled all other sectors of society. At the same time, Mohammed VI has been able to co-opt a significant and powerful sector of civil society, the women's rights movement, and tie it to his project of change for Morocco. Despite some occasional cooperation (Cavatorta 2006), liberal civil society's fear of Islamism is still a prominent feature of Moroccan social dynamics, and has been duly exploited in this case, allowing the monarchy to divide and conquer the opposition because of its ability to dish out selective rewards in exchange for allegiance (Cavatorta 2007).

Women's rights organisations see part of their work as fighting 'extremist Islamist ideas', and perceive Islamism as a problem (Abdou 2008 int.). They therefore also seek alliances to defend the issues they care about in opposition to Islamism. They are obviously aware that siding so clearly with the monarch endangers progress towards meaningful democratisation, but hope that liberal legislation such as the new family code will contribute to 'liberalise' a very conservative polity over time, and therefore be an engine for democratic change in the future, with the king as the guarantor of that change. The downside of this stance is that, for the moment, the more politically sensitive issues that the liberal sector of civil society used to tackle, such as the need to have a serious debate about constitutional reforms that would finally address the problem of the excessive executive powers of the king, have been put on the back burner. Not only that, but the issue of constitutional change is now being promoted by the Justice and Charity Group (Arsalane int. 2005). In terms of the new family code, political Islam and in particular the legal Party of Justice and Development have had to accept a reform that they opposed in order to remain within the game, and are also forced, paradoxically, to invoke the king's role as arbiter if they wish to see some of their preferred policies on other matters implemented, further highlighting the centrality of the monarchy (Hakkaoui 2008 int.).

As mentioned earlier, the manner in which the reform was passed does not diminish the positive aspects of the legislation in terms of equality, but it poses problems on a number of levels. First of all, it is quite clear that such a liberal outcome has been achieved through mechanisms that have reinforced the authoritarianism of the system. One person, unelected and unaccountable, has been responsible for the success of the reform after having emasculated elected institutions, and bypassed the social and political debates necessary to gauge what ordinary Moroccans thought about the reform. While some scholars (Zakaria 2004) argue that democracy will eventually emerge in the Arab world precisely through top-down liberal 
changes, evidence from other countries such as Algeria or Tunisia, and from Morocco itself, so far indicates that quite the opposite is occurring (Christiansen 2004). The absence of meaningful democratic progress in Morocco is detailed in a number of recent studies on the reign of Mohammed VI (Amar 2009; Tuquoi 2006). Secondly, the undemocratic manner in which the changes have been introduced has negative repercussions on the implementation of the legislation on the ground. The women's rights organisations were aware that the passing of the new law would pose challenges for its implementation, and despite campaigns being carried out by some governmental departments and civil society associations, the new provisions of the Moudawana are in fact largely ignored within the judicial system. Old traditions are still dominant. For instance, marriage by fatiha (oral declaration in the presence of two witnesses and God) is still more prevalent than marriage sanctioned by a civil judge. Recent reports by women's organisations confirm that the new provisions are not widely implemented. ${ }^{8}$

There are a number of reasons for the non-application of the legislation, including the poor training of judges, the isolation of large areas of the country, the traditionalism of specific social milieus, the conservative mindsets of officials within the judicial system, and the illiteracy of many Moroccan women. Crucially however there is also a lack of engagement of the monarchy and more generally of the Makhzen in the implementation side of the reform. There is little interest in forcing the concrete application of the law, because this might cause a significant amount of opposition from ordinary citizens, disrupting the political quietism that the king needs. The influential Fournal Hebdomadaire wrote in 2006 that 'the Moroccan authorities are not doing enough to explain the Moudawana to the citizens and to take its application seriously'. ${ }^{9}$ Part of the reason is that the legislative framework is there not necessarily to be implemented across the board, but to showcase Morocco abroad as a liberalising country, and to satisfy the needs of that part of society which is fully integrated into and benefits from the insertion of Morocco into the global liberal economy. This particular constituency is quite distant from the vast majority of Moroccans, who have been left behind during the last decade of economic changes and constitute an important pillar of support for the king, particularly when he delivers reforms that encounter their approval. The final problem is potential reversibility. If political conditions change, and such legislation endangers the preservation of the king's central role and power, he can quite easily reverse it. In short, legislation of this type, rather than being imbedded in the social corpus of the country through a process of information and debate, could function as a bargaining chip. Today, the 
women's movement has come out as the beneficiary, but what if tomorrow the king decides that he needs to please a different constituency, and utilises the family code as a bargaining chip by changing it back? Such a mechanism of reversibility has characterised women's rights in Algeria, for example, where the code was made more regressive in 1984 by the regime in order to satisfy the emerging Islamist movement's demands (Pruvost I999). It remains a tool of social and political control for the Algerian regime.

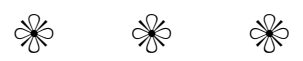

The traditional literature on the role of civil society constantly emphasises that the strengthening of associational life within authoritarian contexts will lead to democratisation. More recent scholarship has provided both theoretical and empirical evidence that this is not necessarily the case. The case of the Arab world quite clearly demonstrates that civil society performs the political function of solidifying existing authoritarian practices. In this respect, Morocco, despite the explosion of civil society activism, follows the Arab trend; and the 2004 reform of the family code, contrary to conventional wisdom, reinforces the central role of the monarch, who is both unelected and unaccountable, and therefore strengthens authoritarian practices. The reform has a liberal outcome, and the new Moudawana significantly improves the legal protections for women and makes them equal partners within the family. The way in which the reform was passed is however highly problematic. Rather than linking it to wider demands for more political pluralism and effective democratisation, the women's movement, realising that its demands might not find the favour of the majority of Moroccans and would create an endless and harsh political debate, bypassed political parties, which did not want to get involved in order to avoid dealing with such an explosive issue, avoided social confrontation, and preferred to rely on the final authority of the king.

Mohammed VI took up the opportunity to reward the women's movement, because of his need to find favour with the international community, and with an influential and politicised sector of society whose support he needs to fend off the Islamist challenge (Beau \& Graciet 2006). Having learned the lesson from the previous decade, women's associations recognised the centrality of the monarchy and deferred the reform to the monarch. For their part, the Islamists have been at pains to argue that their campaign was not against women's rights, but against the imposition of norms that do not make sufficient references to the indigenous value system based on Islam. In any case, they lost out in terms of policy preferences despite constituting the majority. 
The liberal nature of the reform does not guarantee that other liberalising reforms will occur; quite the contrary. For example, following the reform of the family code, the king proceeded to push through very restrictive legislation regarding the formation of political parties, and reasserted his role as the supreme executive power in the country, virtually eliminating the issue of constitutional changes from public debate. The civic associations that fought for the new Moudawana have unwillingly reinforced the authoritarianism of the system, which is for now working in their favour. This does not mean that they have become pillars of authoritarianism, because they are largely attuned to the discourse and practice of democracy. It means however that in the context of a polarised civil society and polity, co-optation by the monarchy in exchange for a reform that they had been struggling for intensely for decades is worth the short-term strengthening of the role of the king.

One of the most significant changes introduced by the new family code is the reform of guardianship, whereby a woman is now empowered to sign her own marriage contract. The virtual elimination of tutorship is certainly a welcome development, and paradoxically highlights the political contradiction at the heart of the reform. Khalil Jemmah (2008 int.) argued that the king should 'give Moroccans the freedom to make their own choices and to end guardianship', just as the family code has abolished tutorship. The current nature of civil society activism seems however to require the guardianship of the king if liberal outcomes are to be achieved.

\section{NOTES}

I. The 'Euro-Med Partnership: Morocco. Strategy Document 2002-2006' of December 200I, available in French at: http://ec.europa.eu/external_relations/morocco/csp/o2_o6_fr.pdf, accessed I I.3.2009.

2. Available in English at: http://ec.europa.eu/world/enp/pdf/country/enpi_csp_morocco_en. pdf, accessed II.3.2009.

3. For an unofficial English translation see: http://www.wluml.org/english/news/moudawanaenglish.pdf; for the official text in French see: http://www.justice.gov.ma/MOUDAWANA/ Codefamille.pdf, accessed 8.3.2009.

4. The Makhzen represents an informal governing alliance between the monarch, his advisers, selected businessmen, high-ranking bureaucrats and tribal chiefs. It operates as the unelected and unaccountable decision-maker in the country beyond the control of the elected government.

5. Excerpts from the speech can be found at: www.surlering.fr/pdf.php/id/336r, accessed 6.7.2009.

6. Excerpts from the speech are found in the 'Rapport parallèle des ONG au rapport périodique du gouvernement du Maroc', Rabat, 2003. The text is available in French at: www.learningpartnership. org/docs/adfmcedawfrenchrep.do, accessed 7.7.2009.

7. Available at: www.oumma.com, accessed 23.3.2009.

8. See for instance the commentary of the ADFM on the implementation of the law five years after it came into effect, available at: http://www.adfm.ma/spip.php?article74I\&lang=en, accessed 27.3.2009. 
9. Cited in 'New Family Code faces many hurdles', available at: http://www.qantara.de/ webcom/show_article.php/_c-478/_nr-545/i.html, accessed 28.3.2009.

\section{REFERENCES}

Amar, A. 2009. Mohammed VI: le grand malentendu. Paris: Calmann-Lévy.

Beau, N. \& C. Graciet. 2006. Quand le Maroc Sera Islamiste. Paris: La Découverte.

Benradi, M., H. Alami, A. Ounnir, M. Mouaquit, F. Boukaissi \& R. Zeidguy. 2007. Le Code de la Famille: perceptions et pratiques judiciaries. Fes: Friedrich Ebert Stiftung.

Berman, S. 2003. 'Islamism, revolution and civil society', Perspectives on Politics I, 2: 257-72.

Brumberg, D. 2002. 'The trap of liberalised autocracy', Foumal of Democracy 13, 4: 56-68.

Buskens, L. 2003. 'Recent debates on the reform of family law in Morocco: Islamic law as politics in an emerging public sphere', Islamic Law and Society I0, I: 70-I3I.

Carothers, T. 1999. Assisting Democracy: the learning curve. Washington DG: Carnegie Endowment for International Peace.

Cavatorta, F. 2005. 'The international context of Morocco's stalled democratisation', Democratization I2, 4: 549-67.

Cavatorta, F. 2006. 'Civil society, Islamism and democratisation: the case of Morocco', Fournal of Modern African Studies 44, 2: 203-22.

Cavatorta, F. 2007. 'More than repression; strategies of regime survival: the significance of divide et impera in Morocco', Fournal of Contemporary African Studies 25, 2: 187-203.

Charrad, M. 200I. States and Women's Rights: the making of postcolonial Tunisia, Algeria and Morocco. Berkeley, CA: University of California Press.

Christiansen, W. 2004. 'Hard-won change in Morocco and Iran', Le Monde Diplomtique, April 2004, available in English at: http://mondediplo.com/2004/o4/o2islamicwoman, accessed 20.3.2009.

Clark, J. 2004. Islam, Charity and Activism: middle-class networks and social welfare in Egypt, Fordan and Yemen. Bloomington, IN: Indiana University Press.

Clark, J. \& A. Young. 2008. 'Islamism and family law reform in Morocco and Jordan', Mediterranean Politics $13,3: 333-52$.

Diamond, L. I994. 'Toward democratic consolidation', Fournal of Democracy 4, 4:4-17.

El-Ghissassi, H. 2006. Regard sur le Maroc de Mohammed VI. Neuilly-sur Seine: Michel Clafon.

Encarnacion, O. 2006. 'Civil society reconsidered', Comparative Politics 38, 3: 357-76.

Ennaji, M. 2008. 'Steps towards the integration of Moroccan women in development', British fournal of Middle Eastern Studies 35, 3: 339-48.

Gellner, E. 1994. Conditions of Liberty: civil society and its enemies. New York: Penguin.

Howe, M. 2005. Morocco: the Islamist awakening and other challenges. Oxford University Press.

Jamal, A. 2007. Barriers to Democracy: the other side of social capital in Palestine and the Arab World. Princeton, NJ: Princeton University Press.

Kubba, L. 2000. 'The awakening of civil society', Journal of Democracy II, 3: 84-90.

Liverani, A. 2008. Civil Society in Algeria: the political functions of associational life. London: Routledge.

Maghraoui, A. 2002. 'Depoliticization in Morocco', Fournal of Democracy I3, 4: 24-32.

Maghraoui, D. 2008. 'The dynamics of civil society in Morocco', in E. Lust-Okar \& S. Zerhouni, eds. Political Participation in the Middle East. London: Lynne Rienner, 193-216.

Pruvost, L. I999. 'Le code algérien de la famille à la recherche d'un projet de société', Cahier d'études berbères 20: 7-2I.

Putnam, R. 2000. Bowling Alone: the collapse and revival of American community. New York: Touchstone.

Rau, Z., ed. I99I. The Re-Emergence of Civil Society in Eastern Europe and the Soviet Union. Boulder, CO: Westview Press.

Roussillon, A. \& F. Z. Zryouil. 20o6. Etre Femme, en Egypte, au Maroc et en Fordanie. Montreuil: Aux Lieux d'Etre.

Sadiqi, F. 2002. Women, Gender and Language in Morocco. Leiden: Brill.

Sadiqi, F. 2008. 'The central role of the family law in the Moroccan feminist movement', British fournal of Middle Eastern Studies 35, 3: 325-37.

Sater, J. 2007. Civil Society and Political Change in Morocco. London: Routledge.

Storm, L. 2008. 'The parliamentary elections in Morocco, September 2007', Electoral Studies 27, 4: $359^{-64}$. 
Tempest, G. 1997. 'Myths from eastern Europe and the legend of the West', Democratization 4, r: I32-44.

Tuquoi, J. P. 2006. Majesté, je dois beaucoup á votre père. Paris: Albin Michel.

Wiktorowicz, Q. 2000. 'Civil society as social control: state power in Jordan', Comparative Politics 33, I: 43-6r.

Willis, M. 1999. 'After Hassan: a new monarch in Morocco', Mediterranean Politics 4, 3: II5-28.

Willis, M. 2002. 'Political parties in the Maghrib: the illusion of significance', Fournal of North African Studies 7, 2: I-22.

Wuerth, O. 2005. 'The reform of the Moudawana: the role of women's civil society organisations in changing the personal status code in Morocco', Hawrwa 3, 3: 309-32.

Zakaria, F. 2004. 'Islam, democracy and constitutional liberalism', Political Science Quarterly I I, I: I-20. Zeghal, M. 2005. Les Islamistes Marocains: le défi à la monarchie. Paris: La Découverte.

Zvan, K. 2007. 'The politics of reform of the new family law', unpublished thesis submitted for the MA in Philosophy in Oriental Studies/Modern Middle East Studies, St Antony's College, Oxford, available at: users.ox.ac.uk/ metheses/Zvan\%2othesis.pdf

\section{Interviews}

Abdou, Mme Bouchra, member of the national bureau of the Ligue Démocratique pour les Droits des Femmes, Casablanca, 3.12.2008.

Akesbi, M. Azzedine, vice-secretary general, Transparency Maroc, Rabat, 25.II.20o8.

Arsalane, M. Fatlallah, spokesperson of the Justice and Charity Group, Rabat, August 2005.

Drissi, Mme Saida, president of the Association Démocratique de Femmes du Maroc, Rabat, 5.II.2008.

Hakkaoui, Mme Bassima, president of the Organisation pour le Renouveau de la Conscience Féminine (ORCF) and PJD member of Parliament, Rabat, II.II.2008.

Jbabdi, Mme Latifa, member, Union de l'Action Féminine, Rabat, I0.7.2009.

Jemmah, M. Khalil, vice-president of the Association Amis et Familles des Victimes de l'Immigration Clandestine, Casablanca, I6.12.2008.

Tbel, M. Said, member of the administrative bureau of Espace Associatif, Rabat, 7.II.2008.

Yassine, Mme Nadia, chairperson of the women's section of the Fustice and Charity Group, Sale, Morocco, 12.12.2008. 